\title{
LEGAL PROTECTION AGAINST NEW CREDITORS IN THE APPLICATION OF CREDIT TAKEOVER WITH MORTGAGE GUARANTEE
}

\author{
Pujiyono; Syarief Toha \\ Faculty of Law, University of Sebelas Maret \\ Email: pujifhuns@gmail.com; syarief.toha@gmail.com
}

\begin{abstract}
This research aimed to identify and analyze legal protection for new creditors in the takeover of credit with mortgage guarantee. Type of Research is a normative legal research or an equation with doctrinal research. The results of this research shows that the implementation of the credit take over with collateral mortgage starting from the loan application by the debtor and all the completeness of the terms of credit application, to do a survey to customers. If it is eligible, then continuing to make a credit proposal in which will be submitted to a credit comitee. If it is approved then continued with the credit agreement and collateral agreement that are required to bring the debtor. Then the bank employees accompany the debt to the former creditor, to make payment with funds obtained from third party to make payment with funds obtained from third party. If the repayment has been done, required to request full payment slip and genuine proof of guarantee ownership, then they can be burden by mortgage, roya has to be done first. The transfer mechanism of mortgage in credit takeover is too risky for a new creditor if the Roya's mail can not be published on the same day. So that way is provide less certainty and legal protection for the new creditors.
\end{abstract}

Keywords: creditor, legal protection, takeover, mortgage

\section{A. INTRODUCTION}

Banks are business entities raising funds from the public in the form of savings and intermediating to the public in the form of credit and / or other forms in order to improve the standard of living of the people.In colloquial the word credit is often interpreted to get the goods by paying installments or installments at a later date or get a loan, which is repaid at a later date with a mortgage or installment agreement. This means that credit can be shaped in the form of goods or money. Either credit in the form of goods or money in terms of payment by installments using a particular method (Kasmir, 2005: 72). Credit is the provision of money or bills can be equated by it, based on

99 Yustisia. Vol. 6 No. 1 Januari-April 2017 Legal Protection Against New Creditors

(C) 2017; This is an Open Access Research distributed under the terms of the Creative Commons Attribution Licensee (https://creativecommons.org/licenses/by/4.0), which permits unrestricted use, distribution, and reproduction in any medium, provided the original work is properly cited. 
agreements between bank lending and other parties requiring the debtor to repay their debts after a certain period of time with interest.

The purpose of credit is to develop economic development based on the principle that with the smallest sacrifice can be obtained maximum benefit it is generally economically credit goal is to make a profit. (Thomas Suyatno, 2007: 15). Carrying out a prudent selection and a permanent supervise for granted loans, requesting collaterals, acquiring external credit insurances, forming provisions to cover losses in advance certainly represents indispensable elements in supporting polities of diminishing credit risk and its negative effects. (Imola Dirga, 2004: 74). Credit guarantees or collateral has a central role when the bank will take the decision to give the creditor to the debtor. It is closely related to the consideration if the debtor has bad credit in the future, the bank can reduce the risk of losses from the lending by using credit guarantees. In Article 1 (23) of the Banking Act states that: "the collateral is additional guarantee submitted debtors to the bank in order to award credit facilities or finance based on Islamic principles." Credit guarantee demanded by banks may be moving objects or object is not moving. Increasing banking competitioncoupled with agency problems, strong balance sheets, and some other characteristics of banking markets (such as risk-related capital requirements, imperfections in the equity market, and maturity mismatches) - may bring about lower credit standards that translate into too-expansionary credit policies and, eventually, higher loan losses". (Gabriel Jimenez and Saurina Jesus, 2006: 52)

In connection with its business activities as intermediary institutions need to be wary of the risk of their deposits that can not be distributed in the form of credit and risk to the fund can not return the loan intermediated. Therefore, the bank conducts a variety of innovations in order to offer his services, one strategy is to do a takeover of credit or refinance loans. Takeover of credit is a term used in the banking world in terms of third party gives credit to debtor who intend to pay off debts / credit debtor to the creditor early and provide new 
loans to borrowers so that the position of this third party to replace the position of the first creditors.

Unlike credit intermediary in general which guarantee/collateral of the debtor can be directly controlled by the creditor when the credit agreement was agreed, in the takeover of credit or refinance loan, collateral can not automatically be submitted by the debtor to the creditor when the credit agreement was agreed because it should be the mechanism of settlement first to former creditors. In fact, Assurance is everything received by the creditor and the debtor submitted to guarantee a debt receivable in the community. (M. Bahsan, 2002: 148) These circumstances make the bank as a new creditor are at a high risk if the debtor in default or the collateral agreement is not perfect. Therefore, in this paper the authors wanted to examine legal protection for new creditors in the implementation of credit takeover with mortgage guarantee.

\section{B. PROBLEM STATEMENTS}

This article aimed to examine how is the legal protection against new creditors in the application of credit takeover with mortgage guarantee?

\section{RESEARCH METHODS}

This type of research is doctrinal research. Data are colected by library research. In this case Sciences understood as the science of law rules (norms), a science that examines the law as a system of rules with the dogmatic law or legal system so that it can be clearly understood rules of law as a science.

\section{THE RESEARCH RESULT AND DISCUSSIONS}

\section{The process of implementing credit takeover with mortgage guarantee}

When banks contract credits that they let use, they can cause economic stagnation and for some sectors to go through a difficult period. Banks can ensure effective distribution of resources in economy by transferring resources that they have collected to certain regions and sectors in need as well. Role of savings is also important for investments that ensure economic growth (Suna Korkmaz, 2015: 70). Banking functions can be seen

101 I Yustisia. Vol. 6 No. 1 Januari-April 2017 Legal Protection Against New Creditors 
from the provisions of Article 3 of the Banking Law, which states that "the primary function of banking in Indonesia are as collector and intermediary of public funds". From this provision reflected the function of a bank as an intermediary parties that have excess funds (surplus of funds) who save their money in banks (in the form of deposits) with the parties deficient and in need of funds (lack of funds) in the form of loans (Jamal Wiwoho, 2011: 37). Bank has a duty to provide credit services (lending) in accordance with the collective agreement and is entitled to repayment of the debtor (customer) and interest. Premises of the debtor, have an obligation to repay the debt and interest as well thereon in accordance with the collective agreement and entitled to the achievement of the form a loan from the bank along with other facilities as per the agreement. (Atika, 2015: 78).

In Article 1 clause (5) of Bank of Indonesia Regulation Number 7/2 / PBI/2005 on The Asset Quality Rating for Commercial Banks provide credit broader definition, as follows:

"Credit is the provision of funds or equivalent claims based on a lending agreement or an agreement between the Bank and another party that requires the debtor to repay the debt after a certain period of time with interest, including: a. overdraft, which is a negative balance on current account customers that can not be repaid in full at the end of the day; b. takeover of bills in factoring; c. takeover or purchase credits from other parties. "

Activities of credit services is considered very important and strategic in banking practices led to the credit management into a point of major concern for management in which the main goal is that bank credit management can maximize the health of the performance of the bank itself by increasing the quantity and quality of credit. The quantity of credit in view and in the value of the amount and rate of growth of outstanding loans, while credit quality in a simple and brief can be measured by the quantity and the portion of bad loans or problematic (Febri Karauwa. 2012: 1). In granting the credit should be guided by the confidence on the ability of debtors to creditors to repay loans on time and the amount corresponding to the contracted (Pujiyono, 2009), it is necessary for the 
Credit Risk Evaluation ie which banks assess the feasibility of debtor to loans in the form of credit risk analysis. Credit analysis ultimately produce estimates the possibility of default or debtor defaults (Baklouti Ibtissem, 2013: 17). Lending procedures in general can be divided between individual loans with a loan by a legal entity, and can also be viewed in terms of its purpose whether for consumption or production. In general, procedures lending by banks is as follows: (Pujiyono, 2012 : 12)

a. Submission of files

b. Inquiry of loan files

c. Interview I : An investigation to potential debtor by dealing directly with the prospective debtor, to ensure whether these files and complete accordance with the bank as desired. The interview was also to find out the wishes and needs of actual customers.

d. Inspection : A field inspection activities by reviewing a variety of objects that will be used as a business or a guarantee, then the result will be matched to the results of interviews I.

e. Interview II : Interview II is the repair of the file if there are deficiencies in the time after on the spot in the field.

f. Credit Decisions

g. Signing of credit agreement/other agreement

h. Credit realization

Broadly speaking, the transition mechanism of credit or takeover is different with the mechanism of banking lending in general, as lending to credit switchover mechanism (take over) only for debtor who at the time it was given credit status as customers of other creditors. Even if the customer already or still become a customer at another creditor, but based on the principle of freedom of contract, the customer is free to decide whom he will bind himself in agreement. (Syamsu Iskandar. 2008: 184). The process of take over starting with a credit application by the debtor, then the submission of all data completeness and terms of credit application, followed by doing a survey by Credit Officer (BI checking, 
trade checking, interviews debtor, checking guarantees), if it has qualified then continued with credit proposal that will be submitted to the credit committee. If the proposal is approved by the credit committee then continued with the signing of the credit agreement and collateral agreement that must be attended by the Bank and debtor. Credit used to credit transition, shall be explicitly stated in the deed of credit agreement which states that the lending partly used for transitional credit facility at the place of origin.

Moreover, the difference mechanism of credit takeover with lending in general is on refinance loans, after the signing of the credit agreement and collateral agreement, then the debtor accompanied by a bank employee new creditors heading to the creditor early to make payment with the proceeds from the new creditor or a third party. In the intermediate credit, the creditor may not obtain the initial two payments on the same debt of the debtor and third parties (Suharnoko, 2005: 3). If the repayment has been made, it shall request slip pins repayment as well as original proof of ownership of collateral that have been burden by mortgage, with roya has to be done first (deletion rights) on behalf of the first creditor. The process of giving a sign of redemption and the write-off slip or roya mortgage notes must be made on the same day as the signing of the credit agreement and collateral agreement. This credit takeover occasion meets the elements contained in the occasion of subrogation, namely the replacement of the creditor rights by a third party, the third party payments made to creditors and occurs because of the agreement made between the debtor and third parties (J.Satrio, 1999: 50 ). Subrogation case with the debtor's obligations are fulfilled by a third party (Kartini Muljadi, 2005: 152). Responsibility fulfilled by a third party is the payment of loan repayment to creditors start to further third parties have become the new creditor on the debtor based on the deed of agreement has been made and agreed between the debtor and third parties. While the function of an agreement in front of notary (in the form of authentic deed) 
before the credit is to ensure the interests of a third party that can replace the old creditors. (Suharnoko., 2005: 10)

Guarantees issued by the debtor to the debtor usually is an object which is then referred to as collateral objects. In a collateral debtors are often asked to pledge personal assets, such as real estate, stocks and bonds, and other personal assets (Raymond Posey and Alan K. Reichert, 2011: 91). Specific guarantees are widely used in the practice of banking activities is a guarantee in the form of ground material. The use of land as collateral for loans, both for the productive and consumptive credit, based on consideration of the land because it is considered the most secure and has a relatively high economic value (Agus Yudha Hernoko, 2010: 7). As a form of legal protection and the rights of creditors, the creditors in this case the bank has stages that must be executed if the debtors default.

"Under either credit insurance or credit guarantee system, if a debtor's credit standing is deteriorating, if the debtor is not able to repay or not willing to cooperate in repaying the debt, financial institutions will take legal actions to protect creditor's rights. After acquiring the executive titles against debtor and guarantor(s), the titles could be used as the basis for recovery of the repayment and request for executing recovery." (Tseng James and Tsung Huang Hsin. 2007: 135-136)

it can be used as collateral for the debt, the state must have a value which can be calculated with the money, because it is a guarantee for the repayment of a debt in the form of money, and should be transferable, because if the debtor breach of contract, then the state as collateral will be sold. In order it can be used as collateral for the debt burdened security rights over the land, in addition to these two conditions, the land concerned must include groups which are listed and expressly designated by law as objects of security institutions concerned. A hypothec-Mortgage is a real right on immovable property made liable for the performance of an obligation. It confers on the creditor the right to follow the property into whose ever hands it may be, to take possession of it or to take it in payment, or to sell it to have a preference upon the proceeds of the sale ranking (Cristea Silvia Lucia, 2012: 4). A mortgagor is the borrower in a 
mortgage - he owes the obligation secured by the mortgage. Generally, the borrower must meet the conditions of the underlying loan or other obligation in order to redeem the mortgage. If the borrower fails to meet these conditions, the mortgagee may foreclose to recover the outstanding loan.( Ketevan Tsintsadze. 2015: 108)

Mortgage characteristics according to the General Explanation of figures 3 Act Number 4 of 1996 on the Mortgage Rights (UUHT) namely:

a. Provide preferred position or the holder first;

b. Always follow the object secured in the hands of whoever the object is;

c. Meet the principle of specialty and publicity so as to bind a third party activities and giving legal certainty to the parties concerned;

d. Easy and be sure about the execution

With regard to the transfer of the Mortgage because of credit takeover or refinance loan, guarantee or collateral does not necessary because law have been transferred to third parties or a new creditor when the loan agreement was agreed because it must go through the mechanism of advance repayment to the first creditors. Repayment need to be done so the old Mortgage can be deleted and liberated then charged back with a Mortgage for the benefit of its new creditors. This is due to the liberation of Mortgage one of them can only happen when the debt secured by the Mortgage has been settled.

The process of repayment is applied by the debtor accompanied by an employee of marketing from the new banks creditor, towards the initial creditor banks in order to pay off their credit worthiness as if its own expenses. This method is adopted to overcome one of the obstacles that are often encountered in practice take over. This obstacle is almost total absence or lack of good cooperation between the bank in terms of the takeover of the credit (Herlien Budiono., 2015: 9). Thus it is not a transfer of the Mortgage from the first creditors to the new creditor but the imposition of the Mortgage in advance between debtors with a new creditors or a third party, then the old mortgage can be released of by using funds from a new 
creditor or a third party (Roya) on the same day, in order to previous guarantee still in the old creditors can be mastered by a new creditors or third parties.

This situation makes the banks as credit takeover or new creditors are at a high risk if the Roya mail can not be published on the same day with the implementation of the take over of credit.

The process of imposition of the mortgage is carried out through two phases, which is:

a. The phase of giving the mortgage, the Mortgage Deed made by the Land Deed Official, then referred to as PPAT, which was preceded by guaranteed debts agreement.

b. The phase of registration by the Land Office, which is the time of the birth of the Mortgage charged.

Besides, in the General Explanation number 7 UUHT stated that:

"At this stage of giving the mortgage by the grantor of the mortgage to the creditor, Mortgage concerned to unborn. Mortgage had only been born when the book of the land was recorded in the Land Office. Therefore, certainty about when the mortgage was registered is very important for creditors. That time it's not only to determine the preferred position to other creditors, but also rank them in relation to other creditors who are also the holders of Mortgage, the same land as the collateral. "

This means that registration of Mortgage is essential to do, in connection with the emergence of the right to claim preferential from creditors, creditors rank position towards others preferred creditor and determine the position of creditors in cases of confiscation.

If the manufacture of mortgage guarantee agreement (APHT) has been done, then in accordance with Article 13 clause (1) UUHT, granting of mortgage deed have to be registered at the Land Office. Furthermore, in Article 13 clause (2) and (3) UUHT determining that the Mortgage registration procedure was performed. The implementation of the Mortgage registration are as follows:

a. After $A P H T$ signed by the parties, witnesses and PPAT, in accordance with Article 13 clause (2) legislation of the mortgage, then no later than 
seven (7) working days PPAT shall send the deed and other warkah which was necessary to the Land Office.

b. Furthermore, Article 13 clause (2) legislation of the Mortgage outlined, that the registration of Mortgage conducted by the Office of land by making the land book of Mortgage and recorded in the land book rights to the land that became the object of Mortgage and copy the records on the land certificates concerned. In the book of land and land rights certificates noting the legal basis for the imposition, Mortgage holder's name, rank Mortgage, insured value and the object of mortgage.

c. Affirmed in Article 13 clause (4) legislation of the Mortgage, that the date of the land book pf mortgage is at the seventh day after the receipt of the complete documents required for registration and if the seventh day falls on a holiday, the land book given dated the next working day. In order to comply with the principle of publicity, the list is open to the public.

Thus the article gives an overview, that the Mortgage has been granted but has not born yet because it has not registered in the Land Office. If APHT already made and signed, then the resulting obligation to register giving the Mortgage. Giving the mortgage set forth in APHT concerned.

Other than that, in Article 1, clause (1) letter d Regulation of the State Minister of Agrarian / Head of National Land Agency Number 5 of 1996 on the Registration of Mortgage stated that:

"For the registration of Mortgage that the object in the form of land rights or the Right of Ownership on Unit Flats are already registered on behalf of the Mortgage, PPAT makes Mortgage deed shall be no later than seven (7) working days after the signing of the Deed submitted to land office required files that consist of the original Certificate of land rights or the right of Ownership on Unit Flats which becomes the object Mortgage."

Based on the above statement, it is known that the time space between the initial loan repayment up to the issuance of Roya mail can be risky, like the first creditors has not been able to issue an initial Roya in other words the original certificate guarantees have not been controlled by the 
new creditor although the credit has been disbursed. This means that imposition of Mortgage which implemented between the new creditor and debtor has not been through the stage of registration, Mortgage, for registration Mortgage requiring the delivery of the original certificate guarantees to the Land Office, in accordance with Article 1 clause (1) letter d Regulation of the Head of the National Land Number 5 of 1996 concerning the Registration of Mortgage.

\section{Legal Protection Against New Creditor In Credit Takeover with Mortgage Guarantee.}

The credit agreement is always associated with a collateral agreement. This is applied by the bank so that the bank received confirmation that the credit given to the client can be used according to need and be able to return safely. Thus, regarding the guarantee that is tied up in the form of a certain collateral agreement will reduce the risk that might occur if the recipient of the credit default or can not repay credit or loans. (Adrian Sutedi, 2012: 24)

The handover of a guarantee by the debtor to guarantee its debts to the Bank is a common requirement in a credit agreement. Although mentioned in Article 1131 of the Civil Code that all material person, whether movable or immovable, either existing or new one will exist in the future, be amenability for any engagement, a partnership, but in the interest of the Bank as creditor, the Bank generally ask guarantees to the debtor to specifically guarantee repayment of debts concerned to the Bank. This is due to the Bank has a position that is given preference in obtaining repayment of the debts to them.

Therefore, the takeover of credit (take over) arising from a credit agreement can not be separated from the takeover of the first creditor rights over collateral guarantees the credit to a new creditor or a third party. This is because in order to protect the interests of new creditors or third parties and to ensure repayment and / or payment of any amount of 
money owed by the debtor to the new creditor or a third party, then in the agreements of credit takeover made between new creditors or third parties the debtor can be agreed upon the delivery of a guarantee by the debtor to the new creditor or a third party.

As described in the previous discussion, that the transfer of collateral pledged with the Mortgage done by through the granting of Mortgage before between the new creditor with the debtor, and then can be released the old Mortgage by using funds from a new creditor so the Roya letter can be published in the same day as the implementation of the credit takeover, so that the original certificate guarantees that previously were still in the first creditor can be transferred to the new creditor. mechanisms like this are actually too risky, because the Roya letter is not necessarily can be published on the same day, so that the new creditor can not enroll while granting Mortgage credit has been disbursed.

Legal protection can be fulfilled if the execution of the takeover of credit (take over) the credit is done in accordance with the provisions of Article 16 of Law Number 4 of 1996 on Mortgage. In that article clearly said that the transfer of credits by way of subrogation rights and authority to divert old creditor to a new creditor. These transfers happen also to guarantee Mortgage relating to credit agreements that lead to credit being diverted. In the case of Mortgage is charged to guarantee the debt of the debtor to the creditor under a credit agreement, the transfer of Mortgage can be done more easily because it does not need to involve many parties. As a new creditor, a third party can immediately receive a certificate of Mortgage and registering the transfer of Mortgage from the old creditor to themselves.

The registration of transition the Mortgage must be done to give preference to the rights for the holders of Mortgage. Mortgage registration is done at the land office in the jurisdiction where the guarantee object of Mortgage was located and registered. Required to register Mortgage, the new creditor is required to bring documents relating to the transfer of 
credit, Including the identity of the assignor and the transferee, the purchase agreement the credit (if any), the agreement on transfer of receivables as well as documents of ownership which should have been in the control of the old creditors.

The process adopted in the transition of Mortgage in connection with the transfer of credit guaranteed by Mortgage was executed through a process. These processes include the registration process transition Mortgage, recording on the land book rights of land which becomes the object of Mortgage as well as the process of copying the records on certificate of mortgage and certificate of land rights are concerned. From the whole process, the transition of Mortgage is valid and binding to the third party since the date in the land book. The date of the recording on the land book was done on the seventh day after the receipt of the complete documents required for registration of transfer of Mortgage. However, if the date of the seventh day falls on a holiday, then the recording was made on the next business day. Announcement regarding the transfer of credit has been made by the new creditor to the Land Office. Announcement and registration carried out by the new creditor intended to the transition of Mortgage is binding / apply to third parties.

\section{E. CLOSING}

On the implementation of the credit takeover with collateral Mortgage, transition of Mortgage is applied by giving the mortgage first among the new creditor with the debtor, and then can be released the old mortgage by using funds from a new creditor so the Roya letter can be published similarly with the implementation of the credit takeover, so that the prevous original certificate guarantees still are located in the old creditor can be transferred to the new creditor. this mechanisms are actually too risky, because the Roya letter is not necessarily can be published on the same day, so that the new creditor can not register the Mortgage deed in order to meet the principle of publicity accordance to Article 13 paragraph (1) UUHT. The new creditor's decision to takeover the Mortgage in the implementation of the take over credit 
with no through this mechanisms as prescribed in Article $16 U U H T$, the result may be in a less fulfillment of legal protection against the new creditor.

In order to fulfil legal protection, then the implementation of the takeover of credit, credit with collateral mortgage, should be applied in line with the provisions of Article 16 of $U U H T$. Based on that article clearly said that the transfer of credits by the effort of subrogation rights and authority to transfer the old creditor to a new creditor. These transfers happen for guarantee Mortgage relating to credit agreements that lead to credit being transferred as well.

\section{BIBLIOGRAPHY:}

Adrian Sutedi. 2012. Hukum Hak Tanggungan (Mortgage Right). Jakarta: Sinar Grafika.

Agus Yudha Hernoko. 2010. Hukum Perjanjian: Asas Proporsionalitas dalam Kontrak Komersial (Law on Contract: Proporsional Principle in the Commercial Contracts). Jakarta: Kencana Prenada Media Group.

Herlien Budiono. 2015. Kumpulan Tulisan Hukum Perdata di Bidang Kenotariatan (The Collection of Civil Law Review in the Notary Sector). Bandung: PT. Citra Aditya Bakti.

Jamal Wiwoho. 2011. Hukum Perbankan Indonesia (Indonesia Banking Law). Surakarta: UNS Press.

J. Satrio. 1999. Cessie, Subrogatie, Novatie, kompensatie dan Percampuran Hutang (Cessie, Subrogatie, Novatie, Compensation, and Debt Mixing). Bandung: Alumni.

Kartini Muljadi. 2005. Hak Tanggungan (Mortgage Rights). Jakarta: Kencana.

Gabriel Jim'enez and Jes'us Saurina, 2006, Credit Cycles, Credit Risk, and Prudential Regulation, International Journal of Central Banking, June 2006, p. 52

Kasmir. 2005. Bank dan Lembaga Keuangan Lainnya (Bank and Financial Institution). Jakarta: Raja Grafindo Persada.

M. Bahsan. 2002. Penilaian Jaminan Kredit Perbankan Indonesia (Assestment of Credit Guarantee Banking in Indonesia). Jakarta: Rejeki Agung.

Suharnoko. 2005. Doktrin Subrogatie, Novasi, dan Cessie (Subrigatie, Novatie, Cessie Doctrines). Jakarta: Kencana.

Thomas Suyatno. 2007. Dasar-Dasar Perkreditan (Basic of Credit). Jakarta: PT. Gramedia Pusaka Utama.

\section{Journals:}

Atika. 2015. "Pemberian Fasilitas Kredit Bank dengan Jaminan Deposito Berjangka (Provision of Bank Credit Facility with Deposit Guarantee)”, Journal "Repertorium". Volume II, No. 2. 
Baklouti Ibtissem. 2013. "Credit Risk Management in Microfinance: The Conceptual Framework", Journal of Finance and Risk Perspective. Vol. 2. Issue 1.

Cristea Silvia Lucia. 2012. "Regulation in the New Romanian Civil Code Practical Aspects".Perspectives of Business Law Journal. Volume I. Issue I.

Febri Karauwa. 2012. "Analisis Kebijakan Kredit Usaha Rakyat Pada Bank BRI Kantor Cabang Pembantu Mega Mas Manado (Analysis of People's Business Credit Policy of BRI)". Journal “Acta Diurna” Ed. 1, Vol. 001.

Gabriel Jimenez and Saurina Jesus. 2006. Credit Cycles, Credit Risk and Prudential Regulation, International Journal of Central Banking. Vol. 1. Number 2.

H.C. Tseng James and Tsung Huang Hsin. 2007. The Analyses of Difference between Credit Guarantee Fund and Credit Insurance, Journal of Accounting, Finance \& Management Strategy. Vol. 3. Number 1.

Imola Dirga. 2004. "Means of Reducing Credit Risk”. Annuals of the University of Petrosani. Economics. Vol. IV.

Ketevan Tsintsadze. 2015. "Mortgage as a Means of Guarantee". European Scientific Journal.

Pujiyono, 2009, "Problematika Penanganan Kredit Macet di Perbankan Pemerintah (Problems of Handling Bad Credit in the Government Bank)". Jurnal Yustisia, Vol 78 (2009).

, 2012, "Eksistensi Model Penyelesaian Sengketa Perbankan Syariah (Existence of Dispute Settelment Model of the Sharia Banking)", Surakarta, Smart Media

Raymond Posey and Alan K. Reichert. 2011. "Terms of Lending for Small Business Lines of Credit: The Role of Loan Guarantees", The International Journal of Business and Finance Research. Volume 5. Issue 1.

Suna Korkmaz. 2015. "Impact of Bank Credits on Economic Growth and Inflation". Journal of Applied Finance and Banking. Volume 5. Issue 1. 